ISSN 1507-3866

e-ISSN 2449-9994

\author{
Anna Król \\ Wrocław University of Economics \\ e-mail: anna.krol@ue.wroc.pl
}

\title{
AN INVESTIGATION OF HEDONIC METHODS APPLICABILITY TO ANALYZING PRICES OF VARIOUS GROUPS OF DURABLE GOODS ${ }^{1}$
}

\section{BADANIE PRZYDATNOŚCI METOD HEDONICZNYCH DO ANALIZY CEN RÓŻNYCH GRUP DÓBR TRWALEGO UŻYTKU}

\author{
DOI: $10.15611 /$ ekt.2015.3.03 \\ JEL Classification: C5
}

\begin{abstract}
Summary: The paper summarizes empirical research finalizing the first stage of the scientific project aimed at hedonic methods application in adjusting price indices in cases when variability in quality of goods is observed. A hedonic model describes the price of the heterogeneous good by a set of its relevant attributes, and thus it can be helpful in distinguishing the price change level resulting from quality-related and other than quality-related causes. As a consequence, hedonic methods provide a group of potential solutions to the problem of measuring a socalled "true price change" by introducing quality-adjusted price indices. However, beforehand a reliable, stable and predictively powerful hedonic model must be constructed and estimated. The main goals of the presented research were: 1 ) to test whether the initially chosen goods are convenient for hedonic analyses; 2) to estimate and verify the hedonic models suitable for further analyses for goods selected in the first step. The empirical research was based on a database consisting of seventeen groups of durable goods (household appliances, consumer electronics and ICT/IT devices).
\end{abstract}

Keywords: hedonic methods, durable goods, prices.

Streszczenie: Artykuł podsumowuje badania empiryczne przeprowadzone w pierwszym etapie projektu naukowego, którego celem jest wykorzystanie modeli hedonicznych w korygowaniu indeksów cen w przypadkach występowania różnic w jakości porównywanych dóbr. W modelu hedonicznym cena dobra heterogenicznego jest wyjaśniana przez zestaw istotnych atrybutów tego dobra, co powoduje, że może on być przydatnym narzędziem przy rozróżnianiu zmian poziomu ceny wynikających z różnic w jakości porównywanych dóbr od

${ }^{1}$ The study was conducted in the framework of the research project entitled The Application of Hedonic Methods in Quality-Adjusted Price Indices (Zastosowanie metod hedonicznych do uwzględniania różnic jakości dóbr we wskaźnikach dynamiki cen). The project has been financed by the National Science Centre on the basis of decision no. DEC-2013/09/N/HS4/03645. 
innych zmian. Tym samym, metody hedoniczne stanowią grupę potencjalnych technik przy rozwiązywaniu problemu mierzenia tzw. „,rzeczywistej zmiany ceny” poprzez odpowiednie korygowanie indeksów cenowych. Do skutecznego i pozbawionego ww. błędu pomiaru zmiany ceny w pierwszej kolejności konieczne jest skonstruowanie i oszacowanie wiarygodnego, stabilnego i efektywnego modelu hedonicznego. Głównym celem przeprowadzonych badań było: 1) sprawdzenie, czy wybrane na etapie zbierania danych grupy dóbr mogą być poddane analizie hedonicznej; 2) oszacowanie i weryfikacja modeli hedonicznych na potrzeby dalszych badań w projekcie dla wybranych dóbr. Badania empiryczne przeprowadzono z wykorzystaniem stworzonych przez autorkę baz danych obejmujących siedemnaście grup dóbr trwałego użytkowania pochodzących z rynków RTV, AGD oraz ICT/IT.

Słowa kluczowe: metody hedoniczne, dobra trwałego użytku, ceny.

\section{Introduction}

Since the end of $20^{\text {th }}$ century in the official price statistics there has been a far-reaching problem concerning the lack of an efficient method of measuring actual price change in cases when the compared goods are of different quality. The importance of this issue has been growing with the rapid progression of technology where the permanent development of production engineering and the emergence of completely new, advanced technologies have caused an acceleration in goods' quality changes. This has led to a situation in which the goods present on the market were not comparable with the goods whose prices were observed in the past (see e.g. [Boskin et al. 1996; Berndt et al. 1995]). As a result, standard methods of price changes measurement have yielded biased results, usually manifested as an overestimation of price growth rates.

Implementing adjustments reflecting quality differences in price indices is discussed in most cases in relation to the Consumer Price Index (CPI). In Poland this index is considered to be the most important price change measure, mainly due to legal and economic implications (see [Łyko 2002]). The CPI constitutes the basis for numerous indicators in Polish legal acts, among others it influences the valorisation of social security benefits (e.g. unemployment allowance), capital indexation (e.g. bonds interest rates) and the level of state and municipal taxes and fees (e.g. real estate tax rates). The economic implications of the CPI indicator are reflected by its importance in the decisions of the Monetary Policy Council in determining the fiscal policy of the state, in government budget construction, and in setting the level of interest rates. In periods when the main objective of monetary policy of the state is to achieve the indicated level of inflation ${ }^{2}$, the Consumer Price Index indirectly

${ }^{2}$ In Poland such a situation took place for example before 2003, when in accordance with the Mid-term Monetary Policy Strategy embraced by the Monetary Policy Council in 1998, the level of inflation should not have exceeded $4 \%$. One of the reasons for inflation suppression at that time was the prospects of Poland joining the European Union. 
influences other economic processes such as the money supply, exchange rates and employment level. In this view the correct measure of price change is fundamental for the monetary and fiscal policy of the state.

The undertaken research project ${ }^{3}$ aims at investigating the applicability of hedonic methods as potential solutions to the problem of measuring so-called "true price change" by introducing quality-adjusted price indices, also called hedonic indices. In order to effectively reduce quality-related biases, first a reliable, stable and predictively powerful hedonic model must be constructed and estimated. The main goals of the presented paper were: 1 ) to test whether the initially chosen goods are convenient for hedonic analyses; 2) to estimate and verify the hedonic models suitable for further analyses for goods selected in the first step.

A hedonic price index is any index which makes use of the hedonic function (see [Triplett 2006]). The basis of hedonic methods are formed by a hedonic hypothesis which states that heterogeneous goods are characterized by a set of relatively homogeneous attributes (characteristics) relevant both from the point of view of the customer and the producer. Moreover it is assumed that there exists a relationship (described by a certain function $f$ ) between the price of the good and its significant characteristics, called hedonic regression (see [Brachinger 2002]). Therefore the price of the good is determined as an aggregate of the values estimated for its each significant characteristic, which may be described in the following general notation:

$$
\text { PRICE }=f(\mathbf{X}, \boldsymbol{\beta}, \varepsilon),
$$

where PRICE is the price of the given good, $\mathbf{X}$ is the vector of characteristics, $\boldsymbol{\beta}$ is a vector of the unknown parameters to be estimated, and $\varepsilon$ is the error term. A correctly specified and estimated hedonic regression model allows to calculate the theoretical price of a given good for a specified set of significant characteristics. This property of hedonic models is crucial for their application in distinguishing the price change level resulting from quality-related and other than quality-related causes. In general, the implementation of hedonic techniques to make adjustments for quality changes consists in incorporating the results obtained from hedonic regressions into classic price index formulas, such as Laspeyres, Paasche or Jevons ${ }^{4}$.

\section{Database description}

The demands on the data for the purposes of hedonic analysis are numerous. First of all the data should consist of a large number of observations, sufficient enough for econometric model estimation to be correctly performed. Secondly, an extensive set of characteristics significant from the perspective of both customer and producer

\footnotetext{
${ }^{3}$ For more information on the project see www.hedonic.ue.wroc.pl.

${ }^{4}$ For practical aspects and recent findings in the field of hedonic price indices construction see e.g. [Aizcorbe 2014].
} 
should be available. Moreover, transaction prices rather than offered prices of the analysed goods are preferable. As in all quantitative analyses, the data should be comparable, as well as relatively clean and reliable. Such data sets are hard to obtain, this being one of the main reasons for the unsatisfactory level of research in the hedonic method area in Poland ${ }^{5}$. For the purpose of the presented research, special infrastructure designed for data collection was developed. The elaborated tool, consisting of mutually related PHP scripts integrated with a SQL database, allowed for the relatively fast and automatic creation of extensive databases suitable for hedonic analyses ${ }^{6}$. The sources of data were price lists available on price comparison service provider's Internet website which was one of the biggest in Poland. The applied method of data collection, called "webscraping", consisting in parsing HTML code from webpages in order to extract the necessary information, is being more often used in price index studies (see e.g. [Cavallo 2013]).

Heterogeneous durable goods, in particular those undergoing very rapid technological development, are one of the most common subjects in empirical hedonic research. The data in the presented study comprises durable goods from three markets: consumer electronics, household appliances and ICT/IT devices. Table 1 presents the seventeen groups of goods present in the initially created database in the second quarter of 2014. The number of observations given in Table 1 refers only to valid and complete observations after the process of outliers detection and removal.

Table 1. Groups of goods in the initial database (Q2 2014)

\begin{tabular}{|c|c|c|c|c|c|}
\hline $\begin{array}{l}\text { Consumer } \\
\text { electronics }\end{array}$ & $\begin{array}{c}\text { Number } \\
\text { of observations }\end{array}$ & $\begin{array}{l}\text { Households } \\
\text { appliances }\end{array}$ & $\begin{array}{c}\text { Number } \\
\text { of observations }\end{array}$ & $\begin{array}{l}\mathrm{ICT} / \mathrm{IT} \\
\text { devices }\end{array}$ & $\begin{array}{c}\text { Number } \\
\text { of observations }\end{array}$ \\
\hline $\begin{array}{l}\text { Car navigation } \\
\text { systems }\end{array}$ & 239 & Coffee makers & 750 & Cell phones & 102 \\
\hline $\begin{array}{l}\text { MP3/MP4 } \\
\text { players } \\
\end{array}$ & 215 & Dishwashers & 273 & \begin{tabular}{|l|} 
Computer \\
monitors
\end{tabular} & 1,164 \\
\hline \multirow[t]{5}{*}{ TV sets } & 803 & Irons & 220 & E-readers & 100 \\
\hline & & $\begin{array}{l}\text { Microwave } \\
\text { ovens }\end{array}$ & 192 & \begin{tabular}{|l} 
Laptop \\
computers
\end{tabular} & 1,388 \\
\hline & & Refrigerators & 545 & Printers & 306 \\
\hline & & Toasters & 148 & Smartphones & 910 \\
\hline & & $\begin{array}{l}\text { Washing } \\
\text { machines }\end{array}$ & 593 & $\begin{array}{l}\text { Tablet } \\
\text { devices }\end{array}$ & 633 \\
\hline
\end{tabular}

Source: own elaboration.

${ }^{5}$ Some of the relevant and recent Polish papers include [Dziechciarz 2004; Tomczyk, Widłak 2010; Witkowska 2014].

${ }^{6}$ A detailed description of the developed tool may be found in [Dziechciarz-Duda, Król 2014]. 
The individual groups of goods were chosen taking into account the availability of the data, the number of observations (at least 100 different models), heterogeneity (presence of significant characteristics influencing the price) and the measurement scale of the independent variables (at least one variable measured on ratio scale). For each observation in each group of goods, price $^{7}$ and all the available significant characteristics were collected.

The process of data collection for the purposes of hedonic indices construction is designed to continue for ten consecutive quarters, starting from Q2 2014 and ending with Q3 2016. In addition to consumer electronics, household appliances and ICT/ IT devices, data for the secondary market of apartments in the five biggest Polish cities (Warszawa, Kraków, Łódź, Wrocław and Poznań), as well as for six groups of used cars (sedans, station wagons, hatchbacks, SUVs, sports cars and vans) are being gathered.

\section{Research methodology notes}

The theory of hedonic methods does not impose the choice of function $f$ that relates the price of a good to its characteristics. Many empirical studies present either the a priori assumption of the functional form of hedonic regression, or the approach of using the functional form which fits the data best. The commonly used mathematical functions in hedonic studies are linear, exponential, double-log and logarithmic (see [Brachinger 2002; Triplett 2006]). In the presented research, BoxCox transformations (see [Box, Cox 1964]) of the dependent variable, as well as the independent variables measured on a ratio scale, were applied in order to assist the process of functional form specification. The method allowed to choose among the linear, exponential and mixed functional forms for each group of goods.

The number and type of characteristics which comprise vector $\mathbf{X}$ depend on the nature of a given good and its technical properties. The determination of significant attributes may be based on technological information concerning production processes, marketing data on the needs and preferences of the consumers, as well as the statistical information obtained from the dataset (see [Triplett 1986]). However, the choice of independent variables is in many cases limited by the availability of data, and therefore the possibility of biases caused by omitted variables must be taken into account. In the presented research the top-down approach to econometric modelling was applied in order to minimize the omitted variable biases. The initial model contained all the available characteristics and was reduced afterwards by rejecting insignificant and/or mutually correlated independent variables. The information criteria (such as AIC, SIC) were used to choose the final model, where necessary.

\footnotetext{
${ }^{7}$ Since data were collected from many sellers, the variable PRICE in each case was calculated as truncated mean, i.e. after discarding $10 \%$ of the lowest and $10 \%$ of the highest prices.
} 
Hedonic regression models face all the classical problems of econometric modelling of cross-sectional data, such as heteroscedasticity of the error term and collinearity of the independent variables (see [Greene 2011; Wooldridge 2010]). Therefore, upon estimation a thorough testing and verification procedure was performed including the areas of significance ( $t$ test, $F$ test), stability (Chow test), heteroscedasticity (White's test), goodness-of-fit (adjusted $R^{2}$ measure), collinearity (variance inflation factors VIF), predictive power (root mean square error RMSE, mean absolute error MAE and mean absolute percentage error MAPE) and normality (Q-Q plot). The applied estimation method was ordinary least squares (OLS), though in cases of heteroscedasticity the models were re-estimated using White's weighted least squares method (see [White 1980]).

\section{Hedonic models for durable goods}

In order to reach the research objectives, the procedure described in the previous section was applied to each of the seventeen groups of durable goods. This led to distinguishing three classes of goods:

1. The goods for which models meeting all quality demands were successfully estimated - these were chosen for further analyses.

2. The goods in cases when the models were statistically correct but provided unsatisfactory goodness-of-fit - these were marked as optional.

3 . The goods for which the research procedure failed to estimate satisfactory models - these were rejected and removed from the database.

\subsection{Chosen groups of goods}

The completely satisfactory estimation results were obtained in the case of eight groups of goods - three representatives of the household appliances market, one representative of the consumer electronics market and four representatives of the ICT/ IT devices market. The estimated models in general were well fitted (with adjusted $R^{2}$ above $75 \%$ ), stable and predictively powerful. Table 2 presents the goodness-offit and significance indicators for groups of goods which belong to this class.

For the sake of conciseness, the results of the estimation for one exemplary group of good - coffee makers - will be discussed in greater detail ${ }^{8}$. The used data set comprises 750 coffee makers variants of 22 different brands available for sale in Internet shops in Poland. Each product is described by its price (PRICE [PLN]) and the following characteristics: engine power (POWER [watt]), type (VACUUM vacuum brewer, SINGLE_SERVE- single-serve coffee maker, DRIP - drip brewer), grinding function (GRINDING), milk frothing function (FROTHER), as well as brand

\footnotetext{
${ }^{8}$ Interested readers may find the detailed results for tablet devices and smartphones in [Dziechciarz-Duda, Król 2015b; Dziechciarz-Duda, Król 2015a] respectively.
} 
Table 2. Goodness-of-fit and significance indicators for the chosen groups of goods

\begin{tabular}{|l|c|c|c||c|c|c|c|}
\hline \multicolumn{1}{|c|}{ Good } & $\begin{array}{c}\text { Number of } \\
\text { observations }\end{array}$ & $\begin{array}{c}\text { Adjusted } \\
R^{2}\end{array}$ & $\begin{array}{c}F \text { test } \\
p \text {-value }\end{array}$ & Good & $\begin{array}{c}\text { Number of } \\
\text { observations }\end{array}$ & $\begin{array}{c}\text { Adjusted } \\
R^{2}\end{array}$ & $\begin{array}{c}F \text { test } \\
p \text {-value }\end{array}$ \\
\hline $\begin{array}{l}\text { Coffee } \\
\text { makers }\end{array}$ & 750 & 0.82519 & $<0.00001$ & Refrigerators & 545 & 0.87711 & $<0.00001$ \\
\hline $\begin{array}{l}\text { Computer } \\
\text { monitors }\end{array}$ & 1,164 & 0.78010 & $<0.00001$ & Smartphones & 910 & 0.90855 & $<0.00001$ \\
\hline Irons & 220 & 0.85023 & $<0.00001$ & $\begin{array}{l}\text { Tablet } \\
\text { devices }\end{array}$ & 633 & 0.84502 & $<0.00001$ \\
\hline $\begin{array}{l}\text { Laptop } \\
\text { computers }\end{array}$ & 1,388 & 0.76221 & $<0.00001$ & TV sets & 803 & 0.83482 & $<0.00001$ \\
\hline
\end{tabular}

Source: own elaboration.

Table 3. Hedonic model for coffee makers; dependent variable: in(PRICE); estimation method: White's weighted least squares

\begin{tabular}{|c|c|c|c|c|c|}
\hline & & & & & \\
\hline & & $\begin{array}{c}\text { Parameter } \\
\text { estimate }\end{array}$ & $\begin{array}{l}\text { Standard } \\
\text { error }\end{array}$ & $t$-ratio & $p$-value \\
\hline & constant & 5.14881 & 0.141172 & 36.4720 & $<0.00001$ \\
\hline & POWER & 0.00023 & 0.000103 & 2.2543 & 0.0245 \\
\hline \multirow{4}{*}{ TYPE } & VACUUM & 1.10430 & 0.185493 & 5.9533 & $<0.00001$ \\
\hline & SINGLE_SERVE & 0.57880 & 0.129644 & 4.4646 & $<0.00001$ \\
\hline & GRINDING & 0.70697 & 0.127492 & 5.5452 & $<0.00001$ \\
\hline & FROTHER & 0.43203 & 0.143827 & 3.0038 & 0.00276 \\
\hline \multirow{11}{*}{ BRAND } & ARIETE & -0.78298 & 0.125622 & -6.2328 & $<0.00001$ \\
\hline & ASCASO & 0.84386 & 0.132687 & 6.3598 & $<0.00001$ \\
\hline & BOMANN & -0.75906 & 0.292562 & -2.5945 & 0.00966 \\
\hline & BUGATTI & 1.54967 & 0.431695 & 3.5897 & 0.00035 \\
\hline & CLATRONIC & -1.15390 & 0.238204 & -4.8442 & $<0.00001$ \\
\hline & JURA & 1.18611 & 0.192967 & 6.1467 & $<0.00001$ \\
\hline & KALORIK & -0.51778 & 0.269877 & -1.9186 & 0.05542 \\
\hline & KRUPS & -0.31418 & 0.149846 & -2.0967 & 0.03636 \\
\hline & OK & -1.0046 & 0.151341 & -6.6377 & $<0.00001$ \\
\hline & SEVERIN & -0.39101 & 0.202236 & -1.9334 & 0.05357 \\
\hline & ZELMER & -0.54353 & 0.166944 & -3.2558 & 0.00118 \\
\hline & Standard error of regression & 4.061263 & \multicolumn{2}{|c|}{ Adjusted $R^{2}$} & 0.825192 \\
\hline & $F(16,733)$ & 221.9808 & \multicolumn{2}{|c|}{$p$-value ( $F$ test) } & $4.7 \mathrm{e}-268$ \\
\hline
\end{tabular}

Source: own elaboration. 
name (BRAND). The Box-Cox method indicated the correctness of the log-linear functional form of the model ${ }^{9}$. Since the presence of heteroscedasticity was detected, White's weighted least squares method was applied in the estimation process. The results are presented in Table 3.

All the variables are statistically significant, and the signs of the parameters are consistent with the expectations. The prices of coffee makers are influenced by their engine power: a 100 watt increase in the engine power results in approximately a $2.33 \%$ increase in the coffee maker's price, ceteris paribus. The price highly depends on the type of coffee machine. Vacuum brewers are over $200 \%$ more expensive, and single-serve makers are over $78 \%$ more expensive in comparison to drip type brewers. The presence of additional features significantly increases the coffee maker's price. The price of an appliance with a grinder is about $103 \%$ higher, whereas the frothing function increases the price by approximately $54 \%$. The estimates for brand variables parameters allow to roughly distinguish three classes of coffee makers brands: the most expensive (Bugatti, Jura and Ascaso), the least expensive (Krups, Severin, Kalorik, Zelmer, Bomann, Ariete, OK, Clatronic), and the middle range (all other brands which are in the reference group, including such producers as Bosch, DeLonghi, Electrolux, Kenwood and Philips) ${ }^{10}$.
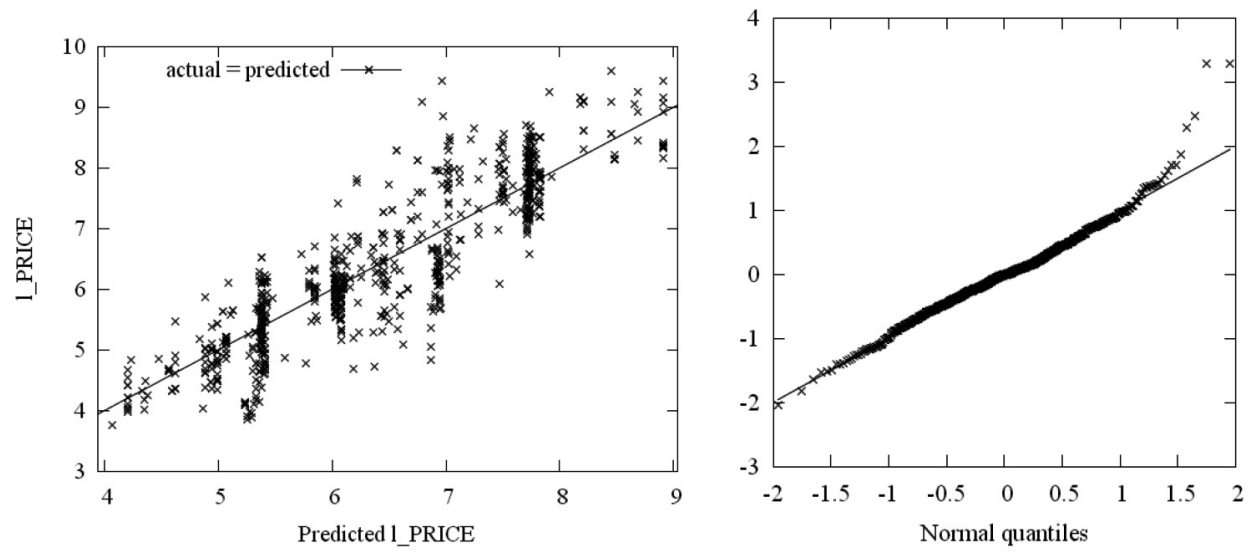

Figure 1. Actual vs. predicted prices and Q-Q plots for coffee maker's hedonic model Source: own elaboration.

The fit of the model is relatively high with adjusted $\mathrm{R}^{2}$ equal to about $82 \%$. The independent variables are free of collinearity (all VIF's are lower than 3) and the

${ }^{9}$ The maximum value of $\log$-likelihood function was obtained for $\lambda$ close to $0(-0.0747)$.

${ }^{10}$ For example, the Bugatti coffee maker's price is higher by about $370 \%$ in comparison to a similar coffee maker produced by a company from the reference group. In turn the cheapest brand - Clatronic - is about $68 \%$ less expensive in comparison to the reference group brands. 
model predicts prices with RMSE equal to 0.6084 , MAE equal to 0.4533 and MAPE equal to $7.2456 \%$. Figure 1 depicts the plot of actual coffee maker's prices against its predicted counterparts and residual Q-Q plot.

\subsection{Optional groups of goods}

For the groups of durable goods presented in Table 4, the estimated models were acceptable in terms of significance and parameters interpretation but provided unsatisfactory goodness-of-fit (around 50-60\%) probably due to the small number of observations gathered and/or omitted variables. In these cases additional analyses are necessary before further research.

Table 4. Goodness-of-fit and significance indicators for the optional groups of goods

\begin{tabular}{|c|c|c|c|c|c|c|c|}
\hline Good & \begin{tabular}{|c|}
$\begin{array}{c}\text { Number of } \\
\text { observations }\end{array}$ \\
\end{tabular} & $\begin{array}{c}\text { Adjusted } \\
R^{2}\end{array}$ & $\begin{array}{c}F \text { test } \\
\text { p-value }\end{array}$ & Good & $\begin{array}{c}\text { Number of } \\
\text { observations }\end{array}$ & $\begin{array}{c}\text { Adjusted } \\
R^{2}\end{array}$ & $\begin{array}{c}F \text { test } \\
\text { p-value }\end{array}$ \\
\hline Dishwashers & 273 & 0.61285 & $<0.00001$ & $\begin{array}{l}\text { MP3/MP4 } \\
\text { players }\end{array}$ & 215 & 0.62444 & $<0.00001$ \\
\hline E-readers & 100 & 0.52492 & $<0.00001$ & $\begin{array}{l}\text { Washing } \\
\text { machines }\end{array}$ & 593 & 0.63573 & $<0.00001$ \\
\hline $\begin{array}{l}\text { Microwave } \\
\text { ovens }\end{array}$ & 192 & 0.54911 & $<0.00001$ & & & & \\
\hline
\end{tabular}

Source: own elaboration.

Table 5 presents the results of a hedonic model estimation for an exemplary optional group of goods - an e-reader. The database consists of 100 e-readers provided for sale in Poland in the second quarter of 2014 by 19 different producers. It includes such variables as SCREEN - screen size [inch], RESOLUTION - screen horizontal resolution [pixel], CARD - memory card slot, as well as brand names variables. The log-linear mode ${ }^{11}$ was estimated using ordinary least squares method.

The price of an e-reader depends on the size and resolution of the screen. With a 1 inch increase in screen size the price of the e-reader increases, ceteris paribus, by about $12.55 \%$, whereas a 100 pixel increase in the screen horizontal resolution ${ }^{12}$ results in approximately a $4.11 \%$ increase in the price. E-readers which are endowed with a memory card slot are on average about $57 \%$ more expensive. The estimates for brand variable parameters may be the basis for the following brand ordination (from the most to the least expensive): Amazon, Iriver, KOBO, PocketBook, Onyx, Sony,

${ }^{11}$ The maximum value of log-likelihood function in Box-Cox transformation was obtained for $\lambda$ close to $0(-0.0101)$.

${ }^{12}$ Since horizontal and vertical resolutions are highly correlated, only one of these two variables was used in the final model. 
Hanvon, Prestigio, TrekStor, the reference group (including the brands: BestBuy, Blaupunkt, Kiano, Lark, Manta, Overmax, SENCOR, Tracer, Vedia and Yarvik).

Table 5. Hedonic model for e-readers; dependent variable: in(PRICE); estimation method: ordinary least squares

\begin{tabular}{|c|c|c|c|c|c|}
\hline & & $\begin{array}{l}\text { Parameter } \\
\text { estimate }\end{array}$ & Standard error & $t$-ratio & $p$-value \\
\hline & Constant & 4.01584 & 0.263175 & 15.2592 & $<0.00001$ \\
\hline & SCREEN & 0.12551 & 0.041195 & 3.0468 & 0.00306 \\
\hline & RESOLUTION & 0.00041 & 0.000139 & 2.9566 & 0.00400 \\
\hline & CARD & 0.45000 & 0.163501 & 2.7523 & 0.00720 \\
\hline \multirow{9}{*}{ BRAND } & AMAZON & 1.13983 & 0.208137 & 5.4763 & $<0.00001$ \\
\hline & HANVON & 0.32157 & 0.175700 & 1.8302 & 0.07064 \\
\hline & IRIVER & 1.01246 & 0.321538 & 3.1488 & 0.00225 \\
\hline & KOBO & 0.70835 & 0.122558 & 5.7797 & $<0.00001$ \\
\hline & ONYX & 0.514448 & 0.119193 & 4.3161 & 0.00004 \\
\hline & РОСКЕТВООК & 0.567168 & 0.096461 & 5.8798 & $<0.00001$ \\
\hline & PRESTIGIO & 0.239365 & 0.108430 & 2.2076 & 0.02991 \\
\hline & SONY & 0.506164 & 0.233606 & 2.1667 & 0.03299 \\
\hline & TREKSTOR & 0.172197 & 0.059864 & 2.8765 & 0,00500 \\
\hline & $\begin{array}{l}\text { Standard error of } \\
\text { regression }\end{array}$ & 0.312458 & \multicolumn{2}{|l|}{ Adjusted $R^{2}$} & 0.524916 \\
\hline & $F(12,87)$ & 10.11534 & \multicolumn{2}{|l|}{$p$-value ( $F$ test) } & $4.15 \mathrm{e}-12$ \\
\hline
\end{tabular}

Source: own elaboration.

The $p$-value in White's test equals 0.1154 , indicating homoscedasticity of the error term. The independent variables are free of collinearity (the highest value of VIF is about 3 for the pair CARD-AMAZON ${ }^{13}$ ) and the mean absolute percentage error equals about $3.8489 \%$.

\subsection{Rejected groups of goods}

For four groups of goods, namely printers, car navigation systems, cell phones and toasters, the obtained results turned out to be unsatisfactory. The majority of parameters in the estimated models were statistically insignificant and their interpretation in many cases was not in accordance with expectations. Moreover,

${ }^{13}$ This is due to the fact that all Amazon e-readers have no memory card slot. 
the models provided unsatisfactory goodness-of-fit. The probable causes for those problems were the:

- small number of observations in the data set,

- possible omitted variables,

- large number of missing observations,

- lack of ratio scale variables significantly correlated with the price of the good.

These groups of goods will be omitted in the subsequent research phases, the data will be removed from the data base and the process of its collection will not be continued.

\section{Conclusions}

In the result of the presented research, the verification of the applicability of hedonic methods to analyzing prices of various groups of durable goods was performed. Out of the initial seventeen groups of heterogeneous durable goods, eight proved to provide reliable and useful hedonic models, five will be further analyzed, and four were found inappropriate for hedonic analyses. This allowed for sorting the goods in the data base and distinguishing those groups which will be subject to the following research consisting in measuring the so-called "true price change" by introducing quality-adjusted price indices, and those which will be rejected. The obtained outcomes should also improve the process of subsequent data collection, shorten its duration and reduce its labor-intensiveness.

In addition, the obtained results may be used for pricing the durables, estimating hedonic prices $^{14}$ for particular characteristics (including the prices which are not directly observable on the market, such as for example the value of brand name), and in combination with the additional multivariate statistical methods for the analysis of consumers' preferences and its application in the market segmentation and pricing policy development (see e.g. [Dziechciarz 2005; Dziechciarz-Duda, Król 2014]).

\section{References}

Aizcorbe A.M., 2014, A Practical Guide to Price Index and Hedonic Techniques, Oxford University Press, Oxford.

Berndt E.R., Griliches Z., Rappaport N.J., 1995, Econometric estimates of prices indexes for personal computers in the 1990s, Journal of Econometrics, vol. 68, no. 1, pp. 243-268.

Boskin M.J., Dulberger E.R., Griliches Z., 1996, Toward a More Accurate Measure of the Cost of Living: Final Report, Diane Publishing Co., Washington.

Box G.E.P., Cox D.R.,1964, An analysis of transformations, Journal of the Royal Statistical Society, Series B (Methodological), vol. 26, no. 2, pp. 211-252.

${ }^{14}$ Hedonic price (also called implicit price) is defined as the part of price relating to a certain characteristic. It indicates how much the overall price changes if the good is endowed with an additional unit of the given characteristic. 
Brachinger H.W., 2002, Statistical Theory of Hedonic Price Indices, DQE Working Papers, 1, Department of Quantitative Economics, University of Freiburg, Fribourg.

Cavallo A., 2013, Online and official price indexes: measuring Argentina's inflation, Journal of Monetary Economics, Elsevier, vol. 60, no. 2, pp. 152-165.

Dziechciarz J., 2004, Regresja hedoniczna. Próba wskazania obszarów stosowalności, [in:] Przestrzenno-czasowe modelowanie i prognozowanie zjawisk gospodarczych, ed. A. Zeliaś, Wydawnictwo Akademii Ekonomicznej w Krakowie, Kraków, pp. 163-175.

Dziechciarz J., 2005, Regresja hedoniczna i metoda conjoint measurement jako narzędzia w kształtowaniu polityki cenowej, Prace Naukowe Akademii Ekonomicznej we Wrocławiu, no. 1096, Wydawnictwo AE Wrocław, pp. 42-55.

Dziechciarz-Duda M., Król A., 2014, Regresja hedoniczna i conjoint analysis w badaniu cen rynkowych i preferencji konsumentów, eds. E. Gatnar, G. Maciejewski, Studia Ekonomiczne. Metody ilościowe w badaniach marketingowych, no. 195(14), pp. 33-43.

Dziechciarz-Duda M., Król A., 2015a, An application of multivariate statistical analysis for the positioning of durable goods brands, Statistics in Transition, in a review.

Dziechciarz-Duda M., Król A., 2015b, Zastosowanie analizy unfolding i regresji hedonicznej do oceny preferencji konsumentów, Taksonomia, no. 25, Wydawnictwo UE Wrocław, for printing.

Greene W.H., 2011, Econometric Analysis, $7^{\text {th }}$ edition, Prentice Hall, Upper Saddle River.

Łyko J., 2002, Pomiar i prognozy inflacji, Wydawnictwo Akademii Ekonomicznej we Wrocławiu, Wrocław.

Tomczyk E., Widłak M., 2010, Konstrukcja i własności hedonicznego indeksu cen mieszkań dla Warszawy, Bank i Kredyt, no. 41(1), pp. 99-128

Triplett J., 1986, The Economic Interpretation of Hedonic Methods, Survey of Current Business, vol. 36 , no. 1, pp. 36-40.

Triplett J., 2006, Handbook on Hedonic Indexes and Quality Adjustments in Price Indexes, OECD Directorate for Science, Technology and Industry, OECD Publishing, Paris.

White H., 1980, A heteroscedasticity-Consistent Covariance Matrix Estimator and a Direct Test for Heteroscedasticity, Econometrica, vol. 48, no. 4, pp. 817-838.

Witkowska D., 2014, Wrażliwość hedonicznych indeksów cen na przykładzie indeksów cen dziet znanych malarzy polskich, Ekonometria, Wydawnictwo UE Wrocław, no. 2(44), pp. 17-30.

Woolridge J.M., 2010, Econometric Analysis of Cross Section and Panel Data, $2^{\text {nd }}$ edition, The MIT Press, Cambridge. 